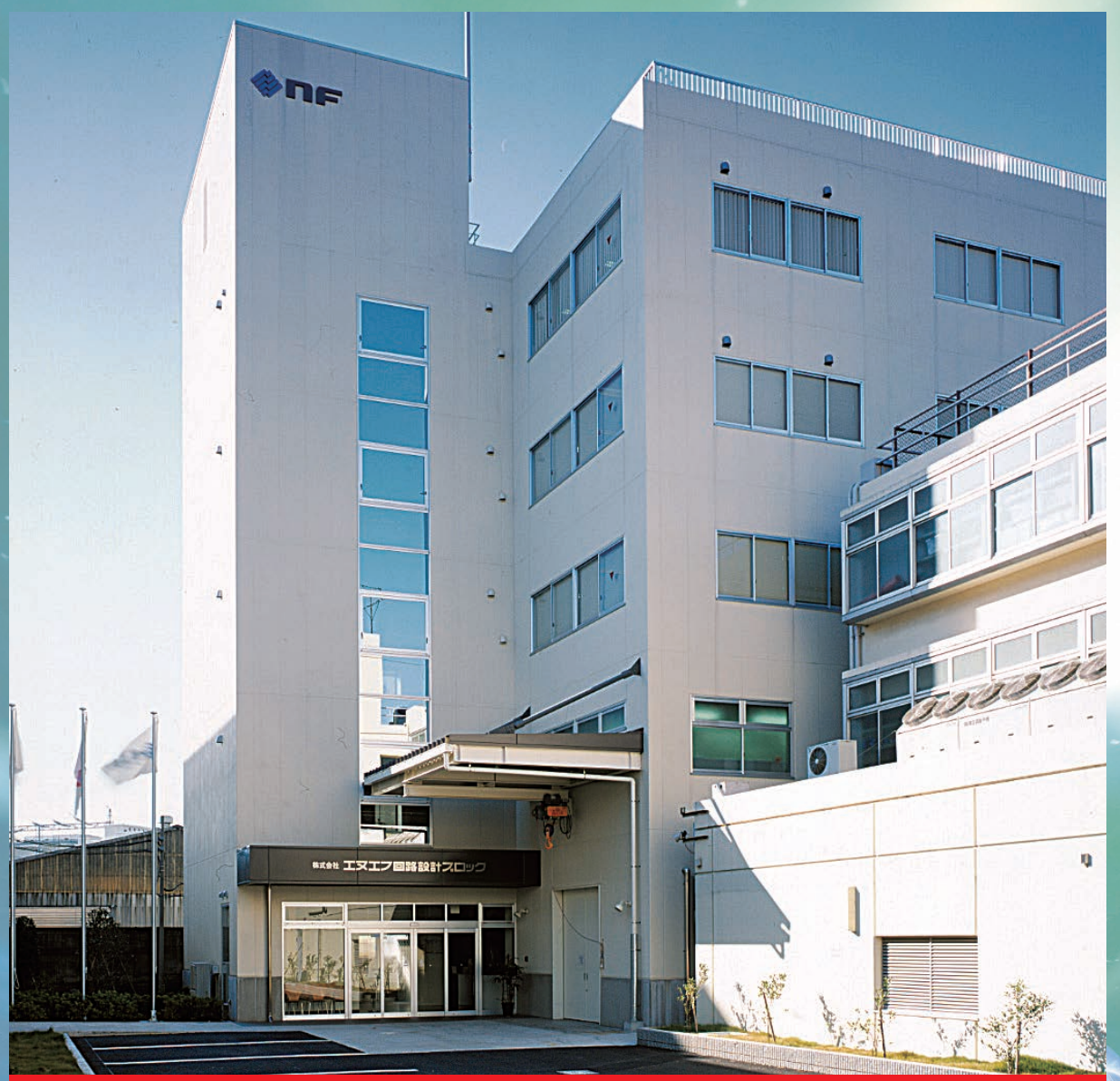

図 1 横浜本社

Cin

Gravure \& Interview 精密工学の最前線

\title{
計測・制御の独創技術で 末来安极
}

(株エヌエフ回路設計ブロック

次世代センサ・アクチュエータ專門委員会
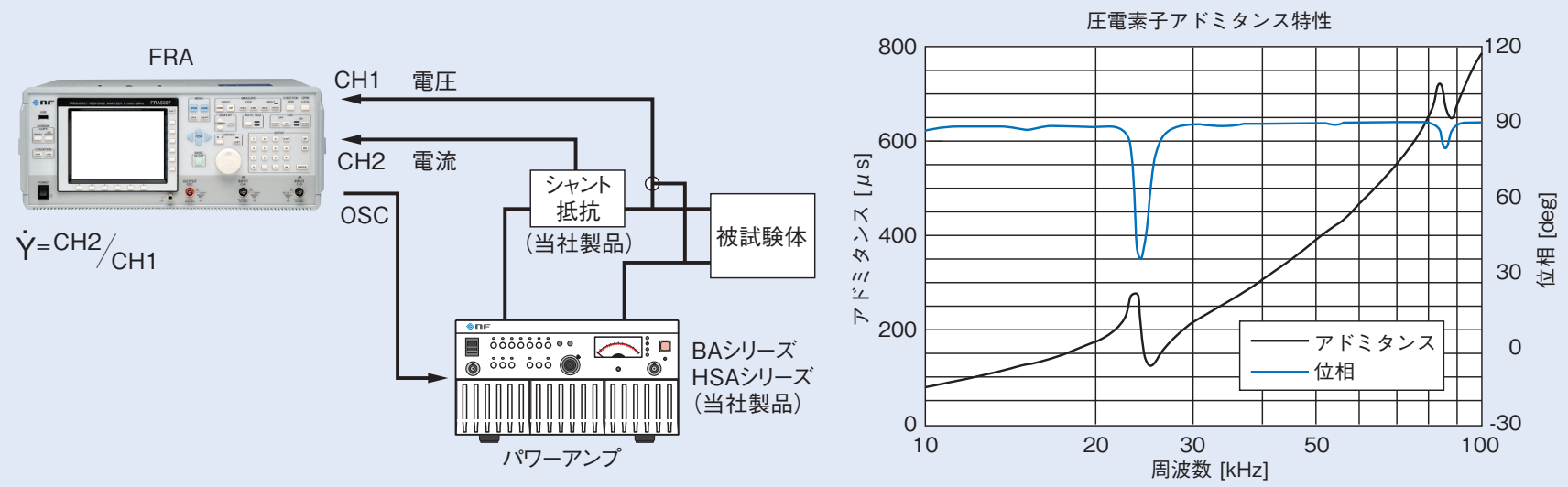

図 2 圧電素子の特性評価 

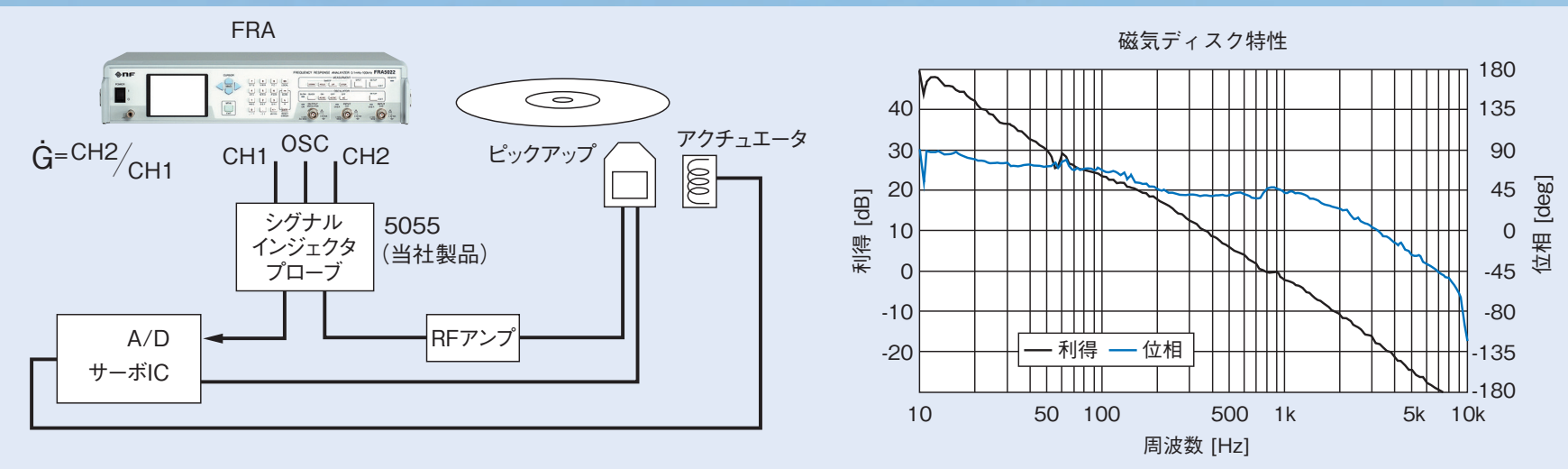

図 3 サーボ特性の評価

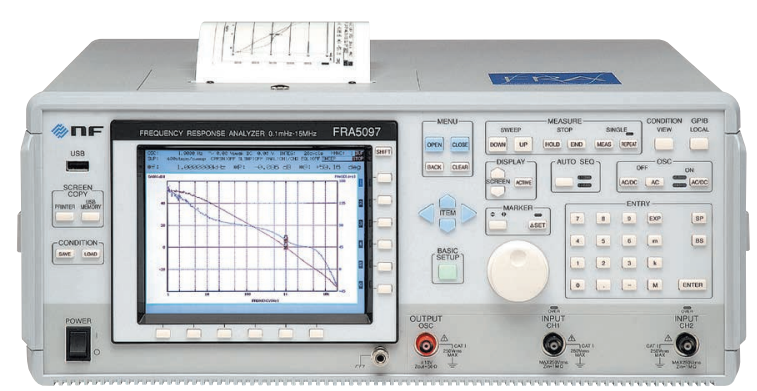

図 4 周波数特性分析器 FRA5097

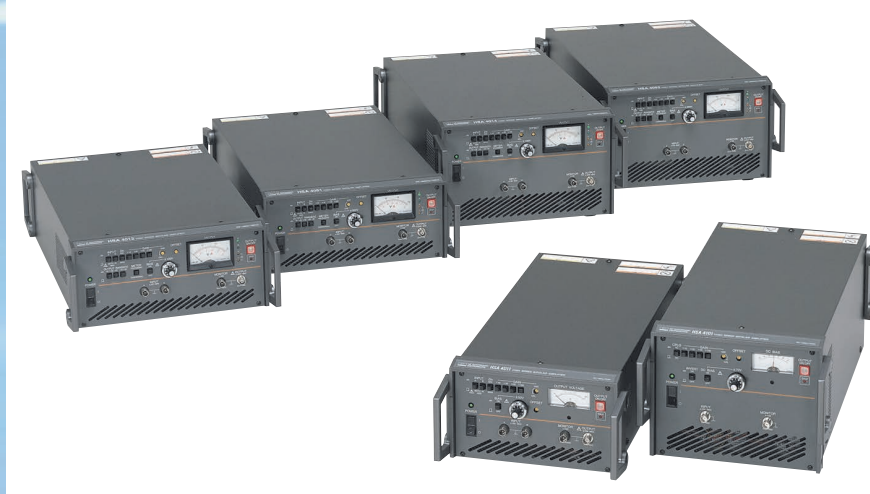

図 5 高速バイポーラ電源 HSA シリーズ
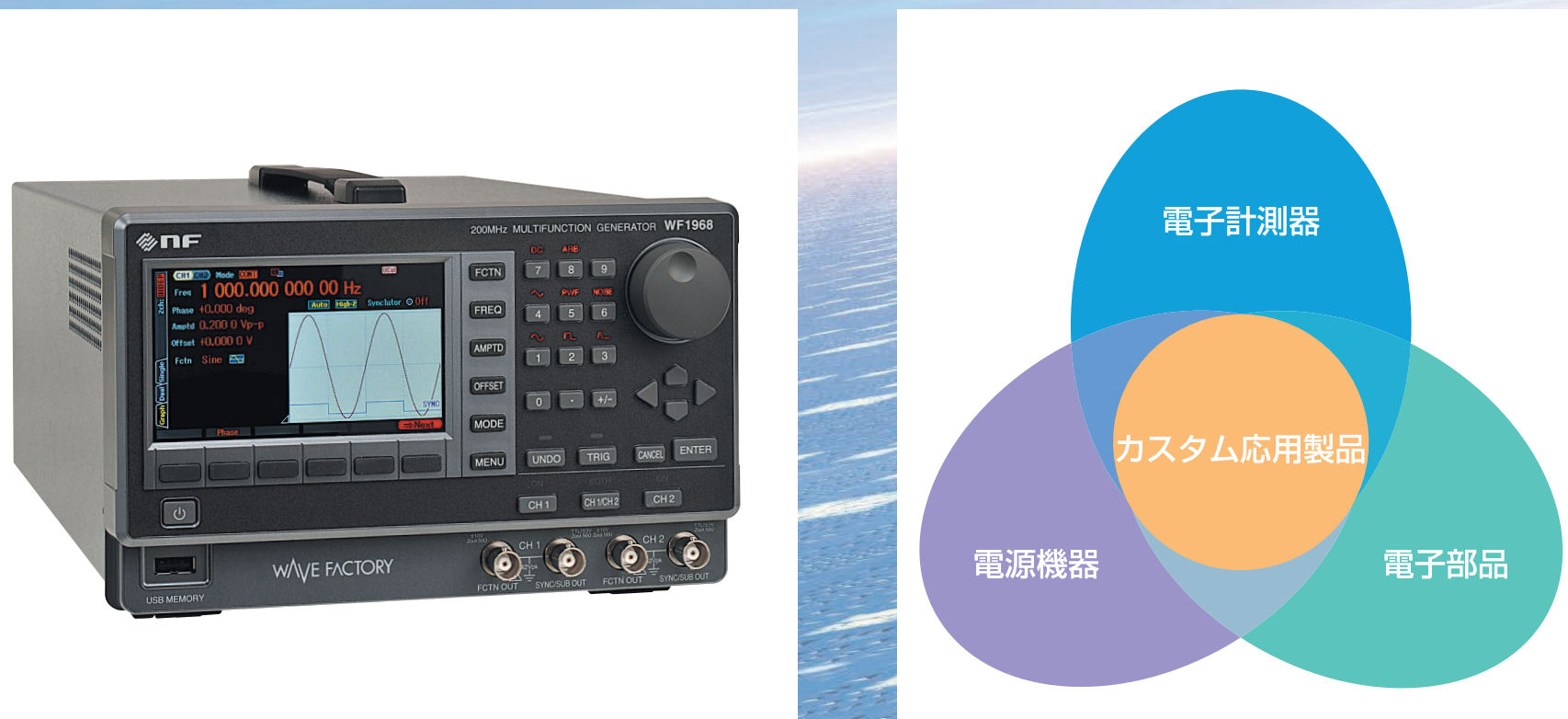

図 6 ファンクション・ジェネレータ WF1968

図 74 つの事業領域 
今回は「次世代センサ・アクチュエー 夕専門委員会」に参画する株式会社工 ヌエフ回路設計ブロック本社を訪問し てお話を伺います．社屋は神奈川県の 横浜市港北区綱島です．昭和の初期に は都心に近い温泉街として栄えた歴史 がある街で，今も駅前にお風呂施設の 煙突が立っています。

Q1 社名がユニークだと思います が，まずは会社概要などをご紹介くだ さい.

弊社は 1959 年， 3 人の技術者から スタートしました，設立前はオーデイ オメーカなどでの経験があり，当初は オーディオ機器用の評価装置やプロ ユースの計測用電子機器を開発してい ました，創業者の一人は日本オーディ 才協会創立時のメンバーでもありま す，社名の「エヌエフ」はネガティブ フィードバック（NF）に由来していま す，NF は今でこそ普及した技術です が創立当時は，この技術に反対する人 もいて論争になっていたそうです，当 時オーディオのピックアップやアンプ の性能はあまりよくなかったので，そ の出力の一部を入力にフィードバック してしまうことには抵抗があったのか もしれません，そんな中，オーデイオ 機器の音質向上や高精度の計測制御に は欠かせない技術としてNFに取り組 んだそうです，当時最先端であった技 術を社名にしたのですから，よっぽど 確信があったのだろうと思います

また，「回路設計」は創業当初の事 情を反映していて，なにしろ 3 人です から電子回路の設計までを専門にする 構想だったそうです，今でいうファブ レスですね。しかし，扮客様は図面で はなく形のある製品を希望されたこと や，アナログ方式の測定器は設計のみ ではなく実装も重要になるので，やは りモノづくりをするメーカとなったよ うです。それと最後の「ブロック」で すが語源はフランス語で, 同じ目的で 集まった集団の集団という意味です。 私は固くなくて緩やかにまとまった組 織と理解しています.いずれにしても

\section{計測・制御の独創技術で末来を拓く}

絑エヌエフ回路設計ブロック 次世代センサ・アクチュエータ專門委員会

株エヌエフ回路設計ブロック

営業推進グループマネージャ

渡部 泰弘 氏

ロ絵グラビア参照 キヤハン(侏) 根岸 真人

創業当初に理想としていた会社の姿を 反映してつけた名前です.

今では事業も 4 つの分野，電子計測 器, 電源機器, 電子部品, そしてカス タム応用製品に広がっています。

\section{Q2 次に専門委員会に入った経緯を お聞かせください.}

専門委員会が設立される前の話です が,「高負荷環境下に扔ける圧電材料 の特性評価」に関する会合がありまし た．その中で圧電素子のインピーダン 又特性, つまり電圧と電流の周波数特 性の測定を共同でやらせていただいた のが発端です，単に特性測定といって も高い再現性で精度よく測定するには ノウハウが必要です。特に高負荷環境 下ではな拉さらです。この仕事の中で さまざまな圧電材料の特性を測定した ことが大変勉強になりました，そのと き, 専門委員会の代表である森田剛先 生に打会いし，そのまま専門委員会に 参加させていただくこととなりました。

\section{Q3 圧電素子の特性評価には技術的} にどんな難しさがあるでしょうか.

電子部品のインピーダンス測定なら LCR メータと呼ばれる測定器を使う のが手軽で一般的です，センシング用 途など，小型の圧電素子であれば測定 時の測定条件と使用時の測定条件が比 較的一致します。しかし，一駆動電圧が
高い圧電素子の場合では測定時と駆動 時の電圧が異なるので, 特性が一致し ません，圧電素子は電圧や温度などに 依存する場合もあります。また，正し い特性を評価するには，使用する状態 にできるだけ近い条件で測定する必要 があります，例えば水中で使用する圧 電素子を大気中で測定しても異なる特 性となる可能性があります。駆動する 電圧の振幅についても，小信号で駆動 する場合と大信号で駆動する場合で特 性が変化することがあります。このた め測定装置には大きな電圧をかけて測 定できることが求められます。例えば LCR メータですと測定電圧が数ボル 卜程度ですが，数十ボルト，もしくは 100 ボルト以上の電圧が必要になる場 合があります，特に，参加していた会 合では目的が高負荷環境下での特性測 定でしたので，電圧の範囲や，使用温 度などの環境も苛酷だったので苦労し ました。

もう一つの難しさは共振のピークが 狭い場合の測定です，例えば水晶振動 子の場合，共振ピークが非常に狭いの で注意深く精密に周波数掃引しなけれ ばなりません。

Q4 特性評価では具体的にどのよう な点に留意すべきでしょうか.

例えば光ディスクのピックアップ特 性やスイッチング電源のルニプ特性な どを測定できる周波数分析器，いわゆ 


\section{Gravure \& Interview 精密工学の最前線}

るサーボアナライザという測定器があ ります．圧電素子の特性測定ではこの サーボアナライザをインピーダンス測 定器として使用します。この際に電圧 増幅用のパワーアンプを組み合わせる のが一般的な測定法です

まず周波数分析器ですが, 共振周波 数が $100 \mathrm{kHz}$ 程度の圧電素子も測定で きなければいけないので少なくともメ ガヘルツレベルの带域が必要です。ま た，鋭い共振ピークに対応するため, 振幅測定に関しても広いダイナミック レンジが必要です。したがって周波数 分析器には, 低ノイズ発振器, そして 精密な電圧測定器と位相測定器が組み 込まれていなければなりません。

また, パワーアンプについても同様, 広い周波数帯域が必要な上に, 出力も 大きくなければなりません，その目的 で高速バイポーラ電源を使いました。 この装置の典型的なスペックは最大出 力 $\pm 150 \mathrm{~V}$, スルーレート $600 \mathrm{~V} / \mu \mathrm{s}$ といったものです。また，圧電素子は コンデンサ特性があり一般的な電圧ア ンプでは十分に駆動ができず正しい測 定ができないことがあります。そのた め特性測定にはバイポーラ出力が久か せません。このような条件が満たされ ないと正しい測定結果が得られなかっ たり，異常発振してしまうこともあり ます

\section{Q5 参加されている専門委員会の様 子についてお聞かせください.}

構成メンバーは大学と企業がおお よそ半々くらいでバランスが取れてい ると思います。委員会は設立されたば かりなのでまだ活動は多くありません が，年に数回開かれる研究会が基本に なっています。研究会では先進的な研 究をされている先生や企業の方が講演 してくれます。質疑も活発で深く突っ 込んだ議論ができていると思います. 圧電材料を研究している先生もいらっ しゃるのですが，材料についての知見 がほとんどなかったので，とても勉強 になります。例えば圧電材料の特性を 測定する理由や動機を知ることができ
ますし，逆に，こうすればもっと上手 に測定できるのにと気ついて提案でき ることもあります。

また，4月には「圧電研究スタート アップ講座」が開催されました。おも な対象はこれから圧電素子の研究を始 める大学生とのことでしたが，基礎知 識の少ない私にとっては非常にありが たい内容でした，委員会メンバーは無 料なのですが, 多くの方が参加して好 評でした。半日かけて 3 人の先生の講 演をじっくり聞けたのと, 懇親会で交 流できたのがよかったと思います。

\section{Q6 委員会をどのように活用してい} らっしゃるのでしょうか.

専門委員会のよいところはまず，一 対一ではなくグループで議論できる点 です．面と向かうとなかなか敷居が高 くて聞けないことでも話しやすい雲囲 気になると思います。そそれに、いつも 固定したメンバーで集まれる点も交流 が深まってよいと思います。議論の内 容も材料, 応用, 計測法などとさまざ まな方向からできます，例えば，さき ほど水晶振動子のような周波数が高く てピークが鋭い圧電材料の例をお話し しましたが，測定条件によっては共振 ピークが現れないことが起こります. そんなとき, 共振が消えたと間違って 判断してしまうかもしれません。でも 計測の経験というか, ノウハウがあれ ば共振が発生していないか，あるいは 設定に問題があるのかの切り分けがで きると思います，私たちは計測器メー カですから計測器のノウハウをもって います．しかし測定対象については知 らないことが多いです，計測のッール を提供するだけでなく，どのように ツールを使ったら正しく測定できて目 的を達成できるのか，お客様と一緒に 測定したり，一緒に考えることが重要 だと思っています。

また，講演会も最新の話題を 1 件づ つ時間をかけるので尃門性が高く,つ いていくのは大変ですがとても勉強に なります，先進的な研究をしている先 生が何を考えて何を測定したいのか，
今は何に関心が向いているのかを直に 感じ取ることができます。

\section{Q7 最後に若手研究者に一言.}

そうですね, アナログ技術の重要性 を強調したいです，実は子供のころか らのオーデイオ好きで，それが進路に 影響し, 最終的には計測器を扱うこの 会社に入りました。当時のオーディオ はアナログの世界でした，今はもうほ とんど見かけなくなりましたがレコー ド盤やカセットテープの世界です，音 を拾うピックアップ部やスピーカーを 駆動するパワー部の電子回路にはさま ざまな工夫，つまりアナログ技術が 注ぎ込まれていました，例えば，初代 ウォークマンが登場したのは 1979 年 のことでしたが，その後 $\mathrm{CD}$ の出現や iPod とどのデジタルプレーヤといっ たデジタル化への劇的な変化があった のはご存知の通りです，圧電素子の計 測に使用される計測器についても同じ で, デジタル化によって機能や性能が 向上しました，しかし急進するデジタ ル化の陰で，アナログ技術が重要であ ることが忘れられていると感じていま す，そのため，アナログ技術を習得し ようとする動機が少なくなっているの かもしれません，それに加えて，デジ タル技術の習得には知識が重要なのに 対し，アナログ技術は経験が重要と思 います，それがアナログ技術者の不足 に拍車をかけているような気がしま す．先ほど計測のノウハウについてお 話させていただきましたが，計測対象 の多くはアナログ信号です。センサや アクチュエータなどの，現実世界と制 御機器のインタフェイスはデジタルで はなくアナログの世界です、オーディ 才機器で考えると, 人とのインタフェ イスはイヤホンやスピーカーなど必ず アナログの世界になっています。デジ タル化で目覚ましく発展した今だから こそ,アナログ技術にこだわりたいと 思います。

貴重なお話をありがとうございまし た.

888 精密工学会誌/Journal of the Japan Society for Precision Engineering Vol.81, No.10, 2015 